Rev. Ter. Ocup. Univ. São Paulo, v. 18, n. 2, p. i, maio/ago., 2007.

\title{
Editorial
}

\section{O Fórum Nacional de Educação das Profissões na Área da Saúde - FNEPAS-: O Desafio da Formação de Profissionais para o Sistema Único de Saúde-SUS}

\author{
Elisabete Ferreira Mângia', Regina Lugarinho
}

O Fórum Nacional de Educação das Profissões na Área de Saúde - FNEPAS, criado em 2004,no contexto do "Seminário Nacional sobre o SUS e as Graduações na Saúde”, promovido pelo Ministério da Saúde, assumiu o compromisso de promover e contribuir para o processo de mudanças curriculares nos cursos de graduação, visando a formação de profissionais habilitados e comprometidos com a Política Nacional de Saúde. Pretende também que tais mudanças sejam orientadas pelos princípios do SUS e das Diretrizes Curriculares Nacionais e particularmente, que desenvolvam na teoria e na prática a concepção/ desafio da Integralidade na atenção em saúde.

Atualmente, o FNEPAS é composto pelas seguintes entidades: Associação Brasileira de Educação Médica (ABEM), Associação Brasileira de Enfermagem (ABEn), Associação Brasileira de Ensino Odontológico (ABENO), Associação Brasileira de Ensino de Fisioterapia (ABENFISIO), Associação Brasileira de Ensino de Psicologia (ABEP), Associação Brasileira de Ensino e Pesquisa em Serviço Social (ABEPSS), Rede UNIDA, Associação Brasileira de Hospitais Universitários e de Ensino (ABRAHUE), Associação Brasileira de Pós-Graduação em Saúde Coletiva (ABRASCO), Sociedade Brasileira de Fonoaudiologia (SBFa) e Rede Nacional de Ensino em Terapia Ocupacional (RENETO).

Com apoio do Ministério da Saúde, esse grupo de entidades vem desenvolvendo um projeto que compreende a realização de oficinas, que visam fortalecer a articulação entre as diferentes profissões e destas com atores estratégicos que compõem o SUS, além de ampliarem, potencializarem e aprofundarem a discussão e a troca de experiências desenvolvidas no contexto de projetos inovadores que busquem integrar ensino, assistência, extensão e pesquisa para o SUS.

Nesse percurso já foram realizadas oficinas por categorias profissionais em todo o país e neste ano serão realizadas oficinas regionais, articulando todos os atores, com o objetivo de proporcionar o compartilhamento entre as profissões dos diferentes olhares e formulações a respeito dos desafios da implementação das diretrizes curriculares nesses dois campos; criar oportunidades para a reflexão conjunta em torno do tema da integralidade, considerado central para a inovação das práticas e da formação em saúde e construir um repertório mínimo compartilhado que subsidie a realização de oficinas e outros movimentos de aproximação regional entre as diferentes profissões da saúde.

Para a Terapia Ocupacional, a participação nesse movimento tem sido muito produtiva e propiciado, no contexto do diálogo com tantas entidades, espaços valiosos de reflexão e troca de experiências, mas gostaríamos que a participação da área fosse ampliada e que mais profissionais pudessem ingressar nesse processo, especialmente nos espaços que serão abertos com a realização das oficinas em todo o país.

Assim, convidamos a todos para juntarem-se a nós nessa construção, para isso sugerimos o acesso ao site do FNEPAS - www.fnepas.org.br para a obtenção de informações sobre a sua região e o contato com os coordenadores de cada uma delas, outra possibilidade é o contato com os representantes da RENETO, pois estamos, em um trabalho artesanal, ampliando nossas parcerias e participação e contamos com você.

\footnotetext{
1 Editora da Revista de Terapia Ocupacional da USP, Prof ${ }^{a}$ Dr $^{a}$ do Curso de Graduação em Terapia Ocupacional da FMUSP. Representante RENETO/FNEPAS.

${ }^{2}$ Diretora Executiva da ABEM/FNEPAS, Prof ${ }^{a}$ Adjunta da Universidade Federal do Estado do Rio de Janeiro.
} 